\author{
원격탐사를 이용한 한반도 주변해역의 해수면/해수온의 \\ 시·공간변동 특성 연구 \\ 오승열 ${ }^{*}$ 장선웅* ${ }^{*}$ 김대현 ${ }^{* *} \cdot$ 윤홍주 $^{+}$ \\ $\left({ }^{* \dagger}\right.$ 부경대학교 $\cdot{ }^{* *}$ 오션테크(주))
}

\title{
Temporal and Spatial Variations of SL/SST in the Korean Peninsula by Remote Sensing
}

\author{
Seung-Yeol $\mathrm{OH}^{*} \cdot$ Seon-Woong JANG ${ }^{*} \cdot$ Dae-Hyun $\mathrm{KIM}^{* *} \cdot$ Hong-Joo YOON ${ }^{+}$ \\ $\left({ }^{*}\right.$ Pukyong National University $\cdot{ }^{* *}$ OCEANTECH CO.)
}

\begin{abstract}
NOAA/AVHRR, Topex/Poseidon, and Jason-1 data were used to analyze sea surface temperatures and thermal fronts in the North East Asia Seas. Temporal and spatial analyses were based on data from 1993 to 2008.

The amplitude and phase for the annual mode on SL and SST were investigated with harmonic analysis. The geographical distribution of amplitudes for comparison of SL and SST are slightly reverse in southwest-northeast tilted direction. The time series analysis conducted on the entire researched area presented consistent pattern. Peak of Sea Level was presented 1 2 months after the peak of the surface sea temperature was shown. This explains that Sea Level change occurs after the generation of surface sea temperature change in sea.

The Sobel edge detection method delineated four fronts. Thermal fronts generally occurred over steep bathymetric slopes. Annual amplitudes and phases were bounded within these frontal areas.
\end{abstract}

Key words : Sea Level, SST, Thermal Fronts, Interannual variations

\section{I. 서 론}

최근 전 지구적으로 이슈가 되고 있는 지구 온 난화 현상과 관련하여 해양의 변화와 기후계 전 체가 상호 어떠한 영향을 미치는지에 대한 관심 이 높다. 우리나라를 포함하여 세계적인 기후변 화와 이상기후로 인한 피해는 매년 증가추세에 있으며 세계 각국은 그러한 피해의 원인과 대책
을 위하여 많은 노력을 하고 있다. 원격탐사 기 술의 발달로 인공위성을 통한 해수면 온도 연구 는 해수면 온도 변화를 통하여 기본적인 해양환 경을 모니터링 할 뿐만 아니라 특수한 해양 특성 과 현상들을 분석 할 수 있다(Everson et al., 1997; Gould and Arnone, 2004; Kang, 1984; Park, 1999).

† Corresponding author : 051-629-6656, yoonhj@pknu.ac.kr

* 이 논문은 2009학년도 부경대학교의 지원을 받아 수행된 연구임(PK-2009-72). 
지구 온난화로 인한 기후변화에서 인간사회에 큰 악영향을 줄 수 있는 인자 중 하나로 해수면 (SL, Sea Level)의 상승이 고려된다. 해수면의 상 승은 생태계 및 사회경제적으로 주요한 연안저지 대 침수, 습지에서의 범람, 해안의 침식, 해수의 유입, 조석의 변화 등 다양한 영향을 주며 한반 도 주변 해역의 경우 평균 해면은 겨울에 낮고 여름에 높은 뚜렷한 계절 변동을 보이는데 그 이 유로는 평균해면과 대기압과의 상호관계에서의 역기압효과 (Lie, 1979), 몬순 영향권에서 해수의 이동방향 차이 (Kang, 1985), 해수의 밀도 변화에 의한 Steric level의 변화 (Lee, 1967; Kang, 1985) 등으로 설명되어 왔다.

해수면 변화에 영향을 미치는 인자 중 하나로 해수면 온도를 들 수 있는데 한반도 주변해역에 서의 1968 2000년까지의 해수면 온도 장기 변 동 추세는 동해에서 $0.022^{\circ} \mathrm{C} / \mathrm{yr}^{-1}$ 로 33 년 동안 $0.72{ }^{\circ} \mathrm{C}$ 상승하였고, 남해의 경우 $0.016^{\circ} \mathrm{C} / \mathrm{yr}^{-1}$ 로 33 년 동안 $0.53^{\circ} \mathrm{C}$, 서해의 경우 $0.03^{\circ} \mathrm{C} / \mathrm{yr}^{-1}$ 로 33 년 동안 $0.99^{\circ} \mathrm{C}$ 상승하였다(서영상 외, 2003).

또한 해수면 온도가 서로 다른 수괴의 만남으 로 형성되는 해양 전선의 변화 분석의 경우 외국 에서는 위성 데이터를 이용한 해양 전선에 대한 연구가 다양한 방식으로 이루어진 바 있으나 (Berkin and Cornillon, 2003; Hickox et al., 2000), 한국 주변 해역에서는 동해와 서해, 동중국해로 각각 세부적으로 연구한 선례는 있으나 이들 연 구들은 실측자료로 연구한 사례가 대부분으로써 본 연구처럼 넓은 해역을 연구대상으로 연구하기 에는 어려움이 있었다(Choi et al., 1993; Isoda, 1994).

본 연구의 목적은 동북아시아의 장기간 위성자 료(NOAA SST, 위성고도계)와 현장 관측 자료를 이용하여 해수면 고도 변화와 해수면 온도 변화, 그리고 해양 전선의 분포의 모니터링으로 시공간 적인 변동 특성 및 상관성과 계절 및 연변화의 양상을 이해하고 앞으로 한반도 주변해역에 대한
해수면 온도와 해수면 고도 변동성을 예측하여 향후 해양 재해예방 및 저감에 기여하고자 한다.

\section{II. 연구 방법 및 자료}

\section{1. 연구해역}

공간적 범위는 한반도를 포함한 북동아시아 해 역으로 $117 \mathrm{E}^{\circ} \sim 142 \mathrm{E}^{\circ}, 25 \mathrm{~N}^{\circ} \sim 45 \mathrm{~N}^{\circ}$ 의 범위로 [그림 1]과 같다.

시간적 범위는 1993년 2008년으로 하였으며 국립해양조사원의 조석자료와 수온 관측 자료를 이용하였다. 조석자료의 경우 국립 해양 조사원 에서 운영하는 고정 검조소 35 개소 중 해역별로 3 곳 씩 배정하여 동해안의 묵호, 울릉도, 포항, 남해안의 거문도, 추자도, 제주 그리고 서해안의 대흑산도, 목포, 군산외항의 총 9개 검조소의 1시 간단위 조위자료이다. 관측 검조소는 조위계 자 료와 일치하는 장소로 선택하였으며 연구기간 동 안 결측이 가장 적은 지점으로 고려하였다.

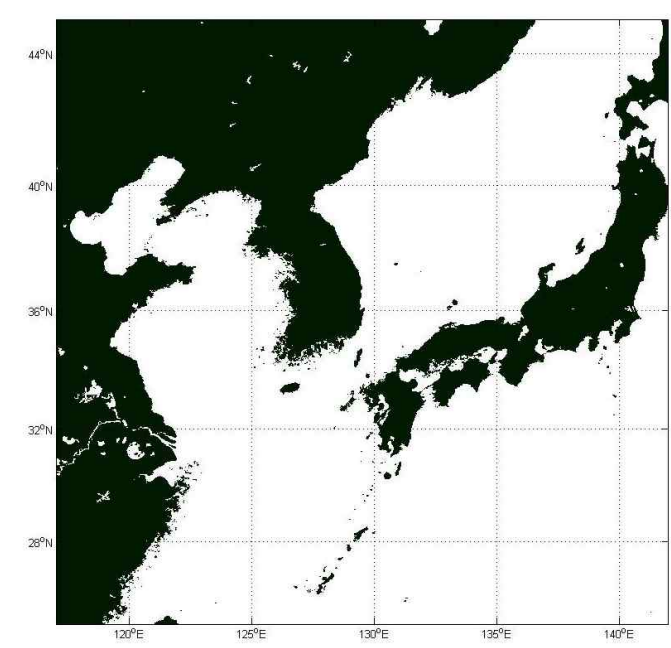

[Fig. 1] Study area

해수면 온도 자료는 $\mathrm{NOAA}$ 제트추진 연구소 PODAAC (Physical Oceanography Distributed Active Archive Center)에서 제공하는 NOAA/ 
AVHRR (National Oceanic and Atmospheric Administration/Advanced Very High Resolution Radiometer) MCSST (Multi-Channel Sea Surface Temperature)자료를 이용하였다. 각 자료는 7일 평균 자료이며 day data와 night data의 합산 평 균치이다.

해수면 고도 편차 자료로는 프랑스 AVISO

(Archiving, Validation and Interpretation of Satellite Oceanographic data)에서 제공하는 SSHA (Sea Surface Height Anomaly)자료로써 T/P와 Jason-1 의 자료를 사용하였다.

\section{2. 연구방법 및 이론}

해수면 고도의 변화를 파악하기 위하여 Topex/ Poseidon과 Jason-1 위성의 영상을 이용하였으며 국립해양조사원에서 관측한 조위계 자료를 비교 하였다. 해수면 온도의 변화는 NOAA/AVHRR 위성자료와 국립해양조사원의 연안정지관측 일일 자료를 비교 분석하였다.

해수면 온도와 고도의 공간 분포와 변화를 살 펴보기 위하여 1993년부터 2008년까지 16년간의 자료를 조화분해 하였다. 또한 해수면 온도와 고 도의 시공간 변화를 분석하기 위해 경험직교함수 (EOF, Empirical Orthogonal Function) 분석을 사용하였다. $\mathrm{EOF}$ 분석은 시공간 변동성을 효과 적으로 제시할 수 있는 방법 중 하나로 각 고유 벡터의 물리적 의미를 규명하지는 못하는 한계가 있지만 단 몇 개의 함수만으로 관측치를 재현할 수 있는 장점을 가지고 있다(나정열 외, 1997). 또한 해수면 변화와 와동류 현상을 파악하기 위 해 RMS (Root Mean Square)공식을 사용하였다.

해양 전선 추출의 경우 온도차가 급격하게 변 하는 부분을 해양 전선으로 생각하여 수온 경사 값을 통해 일정 경계치 이상인 값을 전선으로 결 정하였다. 경계값 추출 연산자 중 Sobel 연산자 는 필터의 가중치가 크기 때문에 다른 방법에 비 해 비교적 좋은 결과를 얻을 수 있고 자료의 오
류가 적어 이를 적용하였다.

\section{III. 결 과}

\section{1. $\mathrm{SST}$ 시공간 분석}

(1) 연안정지관측 자료와 위성 관측 자료와의 비교

일일자료인 연안정지관측 데이터와 7일 합산 자료인 NOAA/AVHRR 데이터를 비교하기 위해 위성영상에서 연안정지관측 지점과 가장 가까운 픽셀 값을 추출하여 상관관계를 알아보았다. [그 림 2]는 $\mathrm{NOAA}$ 위성자료와 연안정지 관측 자료 를 각각 월평균 한 값을 회귀분석 한 것으로 전 조사지점에서 0.9 이상의 높은 상관 값이 나타났 다.

기존의 수행된 위성영상을 이용한 해수면 온도 측정 연구에서도 위성영상 데이터의 신뢰도는 입 증이 되어 현장 조사 자료와 상관이 높이나오는 것은 당연하나 군산, 목포, 포항 등에서 분산이 다른 지점에 비해 크게 나타나는 이유는 각 데이 터의 측정기간의 차이 때문으로 보인다.
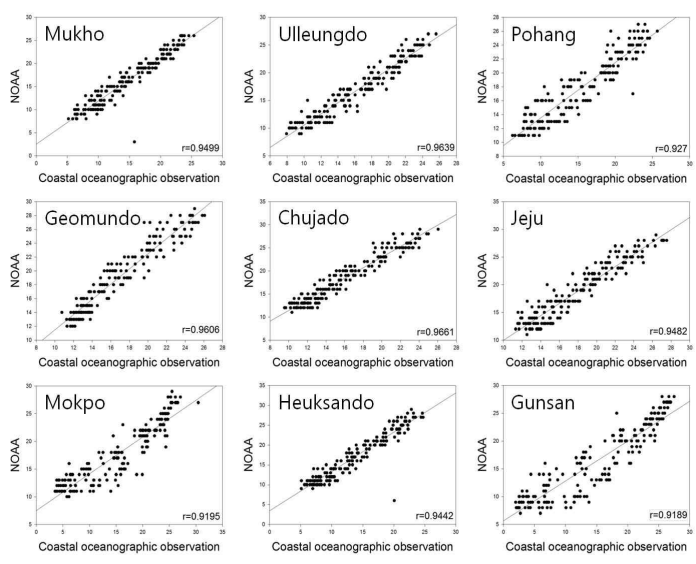

[Fig. 2] Correlation coefficient of NOAA and Oceanographic observation data

(2) RMS 분석

[그림 3]은 해수면 온도의 계절별 RMS 값이다. 
전반적으로 해수면 온도의 변화가 높게 일어나는 곳은 대륙의 근처인 것으로 확인할 수 있는데 그 이유는 연구지역의 위치상 대륙성기후의 영향을 많이 받고 대륙에 가까울수록 기단의 계절별 이 동에 의한 해양과 대기간의 열 교환이 활발해져 외해에 비해 수온의 변화가 크기 때문이다.

계절적으로 보면 여름과 가을에는 쿠로시오 난 류의 영향이 연구해역 전체에 걸쳐 영향을 끼치 며 시베리아 고기압의 영향이 적어 수온의 변화 는 크게 나타나지 않으나 봄과 겨울에는 여름과 달리 난류의 영향이 약해지고 북쪽에서 남쪽으로 향하는 한류의 영향은 커짐과 동시에 시베리아 고기압의 세력이 강해져 동해북쪽의 해역에서 수 온의 변화가 다른 해역에 비해 상대적으로 크게 나타나는 것을 알 수 있다.

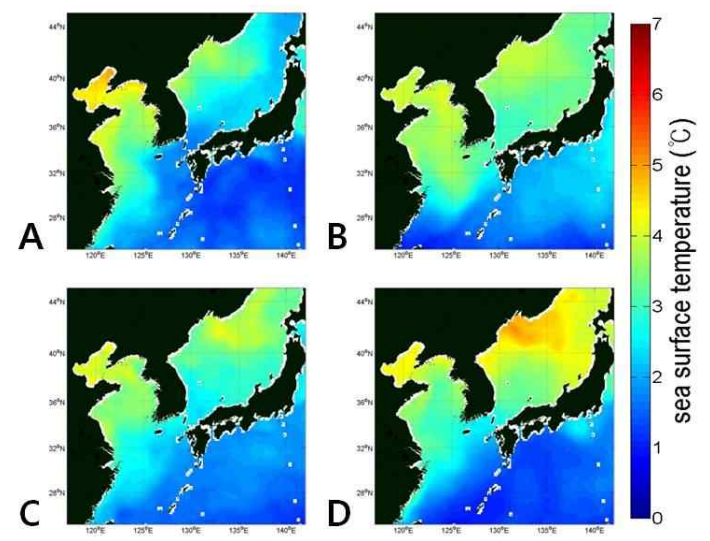

[Fig. 3] RMS of seasonal sea surface temperature (A-Spring, B-Summer, C-Fall, D-Winter)
(3) 조화분해(Harmonic analysis)

그림 4 는 전 연구기간동안의 해수면 온도를 조 화분해 한 결과로 16 년간의 평균 해수면 온도는 연구 해역 전체에 걸쳐 $6 \sim 26^{\circ} \mathrm{C}$ 의 분포를 보였다.

연 진폭은 $3 \sim 11^{\circ} \mathrm{C}$ 의 분포를 보였으며 황해에 서 평균 $8.7^{\circ} \mathrm{C}$ 로 가장 높게 나타났으며, 각 해역 별로 동중국해 북부는 $7.3^{\circ} \mathrm{C}$, 동중국해 남부는 $4.3^{\circ} \mathrm{C}$, 일본 남부해역은 $4.5^{\circ} \mathrm{C}$, 동해 남부는 $6.7^{\circ} \mathrm{C}$ 그리고 동해 북부는 $7.9^{\circ} \mathrm{C}$ 의 분포를 보였다 <Table 1>. 쿠로시오 해류가 통과하는 해역인 동 중국해 남부와 일본 남부해역은 낮은 진폭을 보 였다. 한반도의 황해와 동해북부의 경우 대륙에 근접할수록 진폭 값이 높은 것을 알 수 있는데 이것은 대륙이 외해에 비해 열 교환이 빠르게 일 어남으로 대륙에 가까운 연안은 해수면 온도도 함께 변화하는 것으로 보인다(Yoon, 2001). 황해 와 동해 남부의 경우 비슷한 위도 상에 위치하고 있으나 평균 해수면 온도에서 동해 남부에서 황 해에 비해 $1 \sim 2^{\circ} \mathrm{C}$ 정도 높게 나타나고, 연 진폭에 서는 황해가 동해 남부에 비해 $2^{\circ} \mathrm{C}$ 정도 높게 나 타나는데, 이것은 쓰시마 난류에 의한 열 수송과 한반도의 동해와 황해의 수심차이에 의한 열용량 의 차이를 원인으로 한다. 한반도의 동해남부와 동해 북부에서의 해수면을 통해 공급되는 열과 해류에 의해 공급되는 열을 비교해 보았을 때, 동해남부는 해류에 의한 열 공급이 $60 \sim 70 \%$ 를 차 지하고, 동해 북부는 $10 \%$ 미만을 차지하는 것으로 알려져 있다(한인성, 1998).

$<$ Table $1>$ Comparison between annual amplitude and phase

\begin{tabular}{c|c|c|c|c|c|c}
\hline \multirow{2}{*}{$\begin{array}{c}\text { annual } \\
\text { amplitude }\end{array}$} & Yellow Sea & $\begin{array}{c}\text { northern } \\
\text { East Sea }\end{array}$ & $\begin{array}{c}\text { Northern East } \\
\text { China Sea }\end{array}$ & $\begin{array}{c}\text { Southern } \\
\text { East Sea }\end{array}$ & $\begin{array}{c}\text { Shikoku \& } \\
\text { Tokai Area }\end{array}$ & $\begin{array}{c}\text { Southern East } \\
\text { China Sea }\end{array}$ \\
\cline { 2 - 7 } & $8.7^{\circ} \mathrm{C}$ & $7.9^{\circ} \mathrm{C}$ & $7.3^{\circ} \mathrm{C}$ & $6.7^{\circ} \mathrm{C}$ & $4.5^{\circ} \mathrm{C}$ & $4.3^{\circ} \mathrm{C}$ \\
\hline \hline \multirow{2}{*}{$\begin{array}{c}\text { annual } \\
\text { phase }\end{array}$} & $\begin{array}{c}\text { Southern East } \\
\text { China Sea }\end{array}$ & Yellow Sea & $\begin{array}{c}\text { northern East } \\
\text { Sea }\end{array}$ & $\begin{array}{c}\text { Shikoku \& } \\
\text { Tokai Area }\end{array}$ & $\begin{array}{c}\text { Northern East } \\
\text { China Sea }\end{array}$ & $\begin{array}{c}\text { Southern East } \\
\text { Sea }\end{array}$ \\
\cline { 2 - 7 } & $220 \sim 235^{\circ}$ & $230 \sim 233^{\circ}$ & $235 \sim 240^{\circ}$ & $236 \sim 239^{\circ}$ & $232 \sim 240^{\circ}$ & $232 \sim 238^{\circ}$ \\
\hline
\end{tabular}


연위상은 전체적으로 $210 ~ 250^{\circ}$ (8월)의 분포를 보인다. 동중국해 남부의 연위상은 $220 ~ 235^{\circ}$ 로 최고 수온을 보이는 시기가 8 월 10 일 $\left(220^{\circ}\right)$ 로 가 장 빠르게 나타났으며 이 해역 내에서도 북동쪽 으로 이동하면서 8 월 25 일 $\left(235^{\circ}\right)$ 까지 최고수온을 나타내는 시기가 늦어지는 것을 알 수 있다. 각 해역별로는 황해에서 $230 ~ 233^{\circ}$ 로 8 월 20 일, 동중 국해 북부와 일본 남부해역은 각각 $232 ~ 240^{\circ}$ (8월 30 일), $232 \sim 238^{\circ}$ 로 비슷하게 나타났다. 그리고 동 해 남부는 $240 ~ 244^{\circ}$ (9월 1 일), 동해 북부는 235 $240^{\circ}$ (8월 30일)로 나타났다<Table 1>.

같은 동해상에 위치한 동해 남부와 동해 북부 에서 연 진폭의 경우와 마찬가지로 구분이 되었 는데 이러한 연위상차는 연 진폭차의 원인과도 관련이 있으며 북위 $40^{\circ}$, 동경 $130 \sim 140^{\circ}$ 에서 발 생하는 아극전선대를 중심으로 북쪽인 동해 북부 는 혼합층의 깊이가 동해 남부에 비해 얕아서 해 수면 온도의 감소가 빠르게 일어나고 그로 인해 서 이 두 해역 간 최고 수온을 보이는 시기가 평 균적으로 약 5일가량 차이를 나타내는 것으로 보 인다(Park, 2003).

대체적으로 수온의 연 진폭이 높은 해역에서 최고 수온을 보이는 시기가 빨리 나타나고, 수온 의 연 진폭이 낮은 해역에서는 최고 수온을 보이 는 시기가 늦게 나타났다. 그러나 쿠로시오 해류 가 지나가는 동중국해 남부와 일본 남부해역의 경우는 연 진폭이 낮은 값을 보였지만 연위상도 낮아 최고 수온을 보이는 시기가 가장 빨랐다. 이것은 쿠로시오해류가 적도에서 올라오는 고온 수를 포함한 해류이기 때문에 겨울의 대기 영향 이나 북쪽에서 내려오는 한류의 영향을 적게 받 기 때문인 것으로 사료된다.
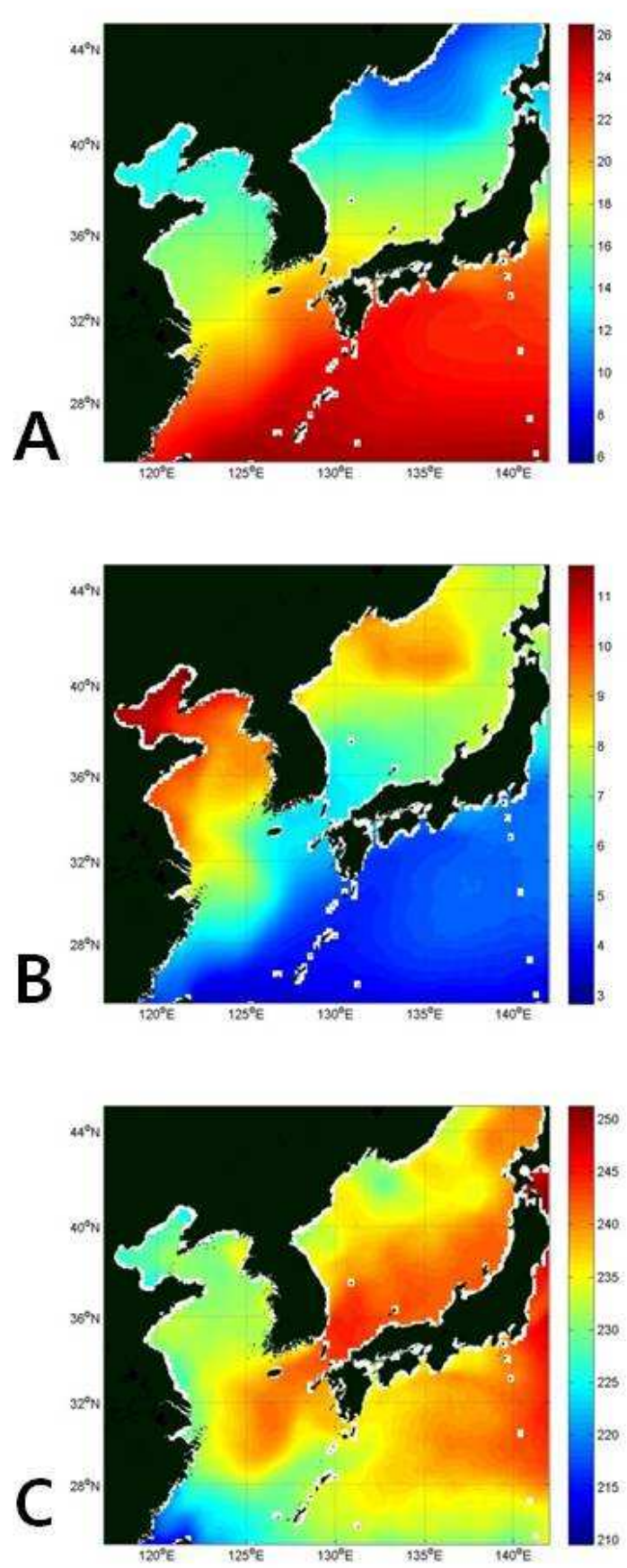

[Fig. 4] Harmonic analysis of sea surface temperature $\left(\mathrm{a}-\right.$ mean $\operatorname{SST}\left({ }^{\circ} \mathrm{C}\right), \mathrm{b}$-annual amplitude $\left({ }^{\circ} \mathrm{C}\right), c$-annual phase $\left.\left({ }^{\circ} \mathrm{C}\right)\right)$ 
(4) 경험직교함수 분석
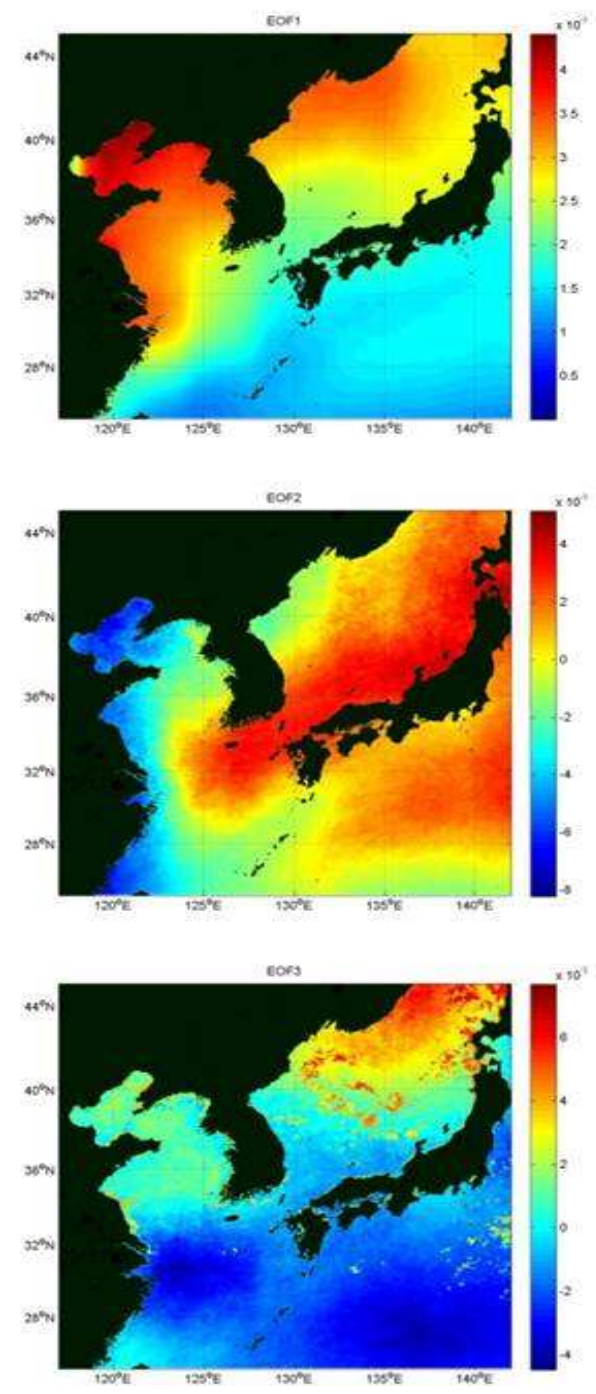

[Fig. 5] EOF of SST

16 년간의 해수면 온도자료를 $\mathrm{EOF}$ 분석하였다. Mode 1 에서의 분산 값은 $97.57 \%$ 로 나타나 연구 해역에서의 시공간적 변화를 설명할 수 있다. Mode 2의 분산 값은 $0.92 \%$, Mode 3은 $0.52 \%$ 로 나타났으며 그 이외의 모드는 더욱 작은 분산 값을 가졌다. Mode 1 의 결과에서 공간분포는 대륙 쪽에 가까워질수록 수온 변화가 커지는 결 과로 조화분해에서 연 진폭의 분포와 비슷하게
나타났다[그림 5]. 시간 계수를 살펴보면 일정한 변화를 관찰할 수 있는데 여름에 양의 최고점을 보이고, 겨울에 음의 최고점을 보임으로 해수면 온도는 계절변화에 가장 큰 영향을 받는다는 것 을 알 수 있다[그림 6].

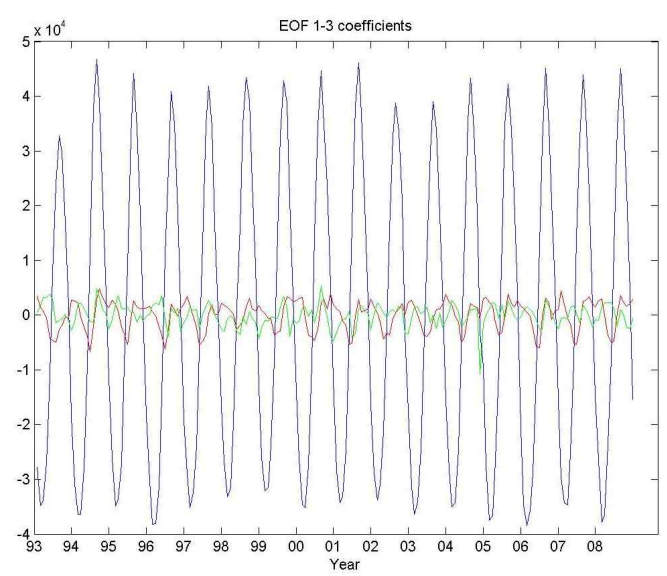

[Fig. 6] Time coefficient of EOF each mode (Blue-mode 1, Red-mode 2, Green-mode 3)

\section{2. $\mathrm{SL}$ 시공간 분석}

(1) 조위계 자료와 위성 관측 자료와의 비교 해수면온도와 마찬가지로 위성영상과 조위관 측자료를 비교하기 위하여 위성영상 데이터 중 조위관측소와 가장 근접한 픽셀의 값을 추출하 여 회귀 분석하였다.

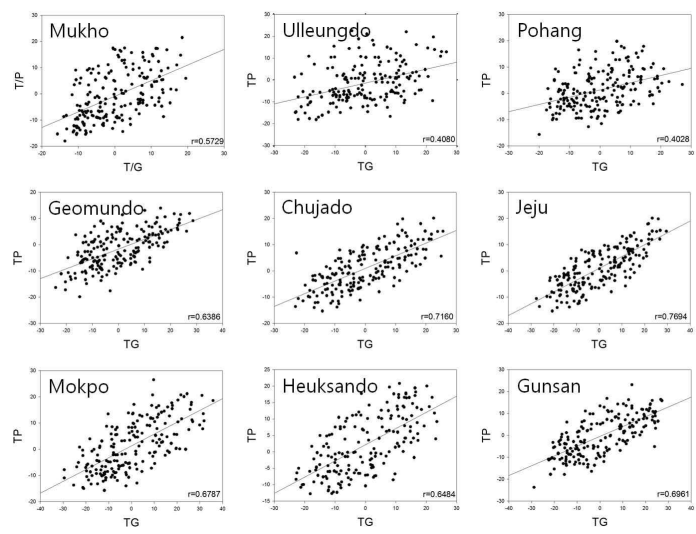

[Fig. 7] Correlation coefficient of $\mathrm{T} / \mathrm{G}$ and $\mathrm{T} / \mathrm{P}$ 
[그림 7]는 Topex/Poseidon 위성자료와 조위 관측 자료를 각각 월평균 한 값을 비교한 것으 로 한반도 연안의 조위관측지점과 가장 가까운 픽셀의 위성자료와 상관도 분석을 한 것이다. 거 문도와 제주, 그리고 군산 외항과 같이 비교적 외해에 위치한 지점에서 각각 $0.7160,0.7694$ 그 리고 0.6961 로 높은 상관성을 나타내었다. 해수 면 온도의 경우와는 다르게 상관 값이 낮게 나 타나는 것을 확인할 수 있는데 이것은 $\mathrm{T} / \mathrm{P}$ 의 경우 연안에서는 그 정확도가 낮게 나타나기 때 문인 것으로 사료된다(윤용훈, 2002).

(2) RMS 분석
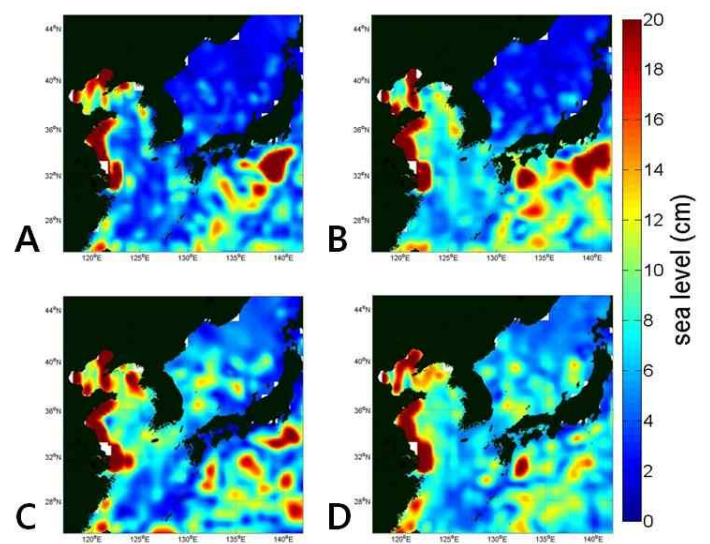

[Fig. 8] RMS of seasonal sea level (A-Spring, $\mathrm{B}$-Summer, C-Fall, D-Winter)

[그림 8]은 해수면의 계절별 RMS 결과이다. 한반도의 서해, 특히 중국의 연안에서 낮은 수심
과 큰 조석차로 인해 모든 계절에 걸쳐 높은 값 을 보였다. 또한 일본의 남쪽 해역에서도 높은 $\mathrm{RMS}$ 값을 보였다. 중국의 동쪽 연안은 양쯔강 과 황하의 영향으로 중국 연안수의 세력이 강해 연중 높은 해수면 변화 폭을 보인다. 한반도의 서쪽 연안에서 관찰되는 높은 값은 조석의 영향 때문인 것으로 사료된다.

한반도의 주변에서는 울릉도 근처에서 연중 주변의 해역에 비해 높은 변화 값을 보였는데 그것은 쓰시마 해류의 지류 중의 하나인 동한 난류에 의한 영향과 울릉도 주변 해역에서 거의 일정하게 나타나는 울릉도 warm eddies 에 의 한 것으로 사료된다.

\section{(3) 조화분석}

[그림 9]는 연구기간동안 평균 해수면의 조화 분해 결과를 나타낸 것이다. 연구해역에서 평균 해수면은 $1 \mathrm{~cm}$ 내외로 관찰되었다. 해역별 평균 해수면 변화량을 살펴보면, 황해는 $0.68 \mathrm{~cm}$, 동중 국해 북부는 $1.01 \mathrm{~cm}$, 동중국해 남부는 $0.92 \mathrm{~cm}$, 동 해 남부는 $1.01 \mathrm{~cm}$, 동해 북부는 $0.89 \mathrm{~cm}$ 로 나타났 으며 황해는 다른 해역에 비해 낮은 분포를 보 였고, 동중국해 북부와 동해 남부에서 평균적으 로 높은 분포를 보였다<Table 2>. 특이점으로는 일본의 남쪽해역에서 $3 \sim 6 \mathrm{~cm}$ (Cyclonic)와 $-4 \sim$ $-12 \mathrm{~cm}$ (Anticyclonic)의 큰 분포가 나타나는데 이 는 쿠로시오 해류의 영향으로 발생하는 와동류 (eddy)로 강한 쿠로시오 해류의 흐름으로 인해 연중 복잡한 해류의 흐름을 보이는 지점이다.

$<$ Table 2> Comparison between annual amplitude and phase

\begin{tabular}{c|c|c|c|c|c|c}
\hline \multirow{2}{*}{$\begin{array}{c}\text { annual } \\
\text { amplitude }\end{array}$} & $\begin{array}{c}\text { Shikoku \& } \\
\text { Tokai Area }\end{array}$ & $\begin{array}{c}\text { Northern East } \\
\text { China Sea }\end{array}$ & $\begin{array}{c}\text { Southern } \\
\text { East Sea }\end{array}$ & Yellow Sea & $\begin{array}{c}\text { Southern East } \\
\text { China Sea }\end{array}$ & $\begin{array}{c}\text { northern } \\
\text { East Sea }\end{array}$ \\
\cline { 2 - 7 } & $13.85 \mathrm{~cm}$ & $10.18 \mathrm{~cm}$ & $9.55 \mathrm{~cm}$ & $8.84 \mathrm{~cm}$ & $8.55 \mathrm{~cm}$ & $5.92 \mathrm{~cm}$ \\
\hline \hline \multirow{2}{*}{$\begin{array}{c}\text { annual } \\
\text { phase }\end{array}$} & $\begin{array}{c}\text { Shikoku \& } \\
\text { Tokai Area }\end{array}$ & Yellow Sea & $\begin{array}{c}\text { Southern East } \\
\text { China Sea }\end{array}$ & $\begin{array}{c}\text { Northern East } \\
\text { China Sea }\end{array}$ & $\begin{array}{c}\text { Southern } \\
\text { East Sea }\end{array}$ & $\begin{array}{c}\text { northern } \\
\text { East Sea }\end{array}$ \\
\cline { 2 - 7 } & $216 \sim 259^{\circ}$ & $219 \sim 241^{\circ}$ & $223 \sim 260^{\circ}$ & $245 \sim 248^{\circ}$ & $252 \sim 280^{\circ}$ & $256 \sim 20^{\circ}$ \\
\hline
\end{tabular}



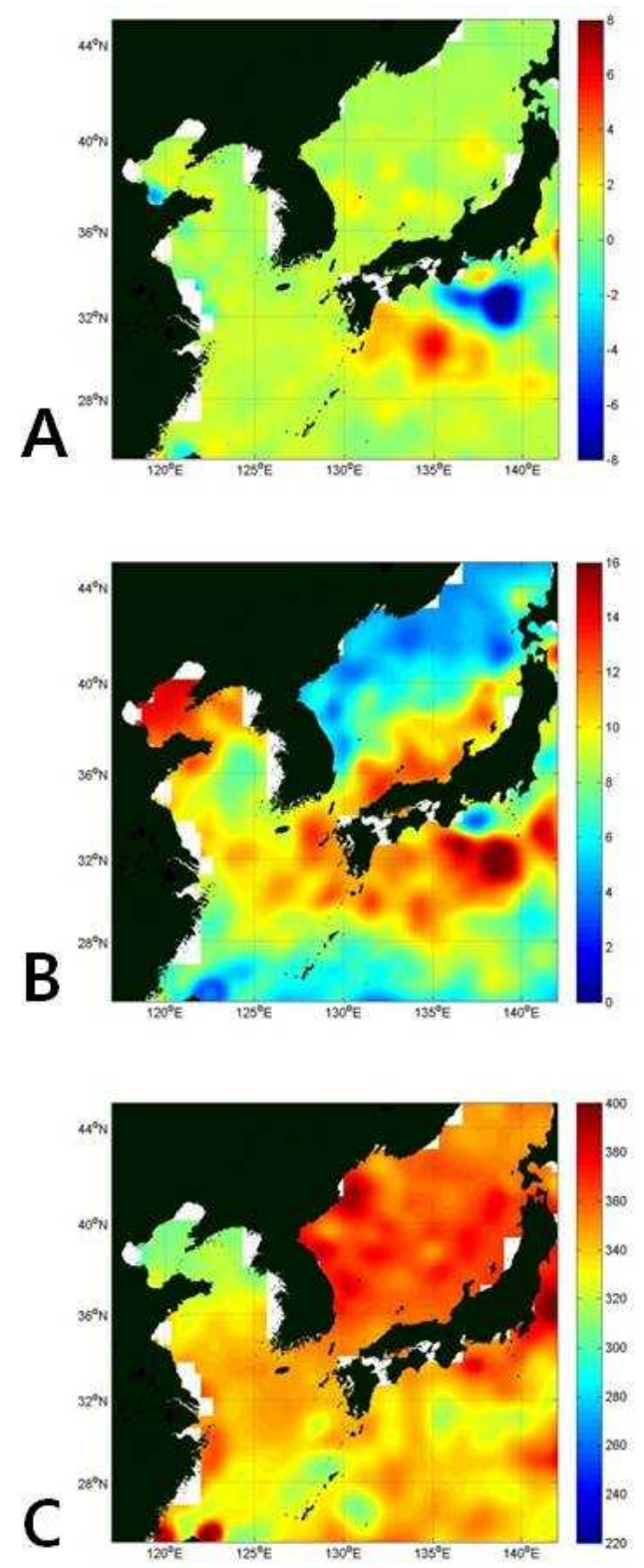

[Fig. 9] Harmonic analysis of sea level (a-mean SLA $(\mathrm{cm}), b-$ annual amplitude (cm), c-annual phase $\left(^{\circ}\right)$ )

연구해역에서 해수면의 연 진폭 분포는 $4 \sim 16 \mathrm{~cm}$ 로 나타났다. 주로 쿠로시오 해류의 영향을 강하 게 받는 해역에서 높은 값을 나타냈는데 동중국 해 북부에서 평균 $10.18 \mathrm{~cm}$, 일본 남부 해역에서
평균 $13.85 \mathrm{~cm}$ 로 진폭 값이 높았고 연구해역에 포 함되지는 않지만 보하이 만에서 평균 $13.19 \mathrm{~cm}$ 로 진폭이 높게 나타났다. 한반도의 동해에서는 동 한난류와 북한한류가 만나는 열전선과 비슷한 모습으로 연 진폭이 나타났다.

연위상은 전체 연구 해역에서 $1953^{\circ}$ 의 분 포를 나타냈다. 전반적으로 한반도를 중심으로 서쪽과 남쪽의 해역은 최고 해수면 높이를 보이 는 시기가 빠르고 한반도의 동쪽은 상대적으로 낮은 분포를 보였다. 해역별로 해수면 최고 높이 를 기록하는 시기를 살펴보면 황해는 219 $241^{\circ}$ 의 분포로 8 월로 나타났으며, 동중국해 북부는 245 248 (9월 초)의 위상분포를 보였고 동중국 해 남부는 223 260 , 일본 남부 해역은 216 259 로 8월 중순 9월 중순에 최고 해수면 높이를 보 였다. 동해 남부는 252 280 , 동해 북부는 256 $280^{\circ}$ 로 9월 말 10월 초에 걸쳐 최고 해수면 높이를 보였다<Table 2>. 해수면 온도의 연 위 상과 비교해 보였을 때 동일한 해역에서 해수면 온도가 최고 수온을 기록하고 그로부터 1 2개월 후에 해수면이 최고 높이를 기록한 것을 알 수 있다.

(4) 경험직교함수 분석

[그림 10]은 16년간의 해수면 고도자료를 $\mathrm{EOF}$ 분석한 것이다. Mode 1에서의 분산 값은 $50.80 \%$ 로 나타났으며 Mode 2의 분산 값은 $17.17 \%$, Mode 3은 $10.92 \%$ 로 나타나 해수면 고도에 작용 하는 영향을 살필 수 있다. 해수면 온도의 경우 mode 1 의 분산 값이 $97 \%$ 이상을 기록하며 해수 면 온도에 영향을 미치는 주성분으로는 계절변 화가 가장 우세하며 나머지 성분들의 영향은 미 미한 것으로 나타났지만 해수면의 경우는 mode 1 이외에도 mode 2 와 mode 3 의 분산 값이 높 은 것으로 보아 계절적인 영향 외에도 해수면 변화에 영향을 미치는 성분이 많은 것으로 보인 다.

Mode 1의 공간분포를 살펴보면 쿠로시오의 

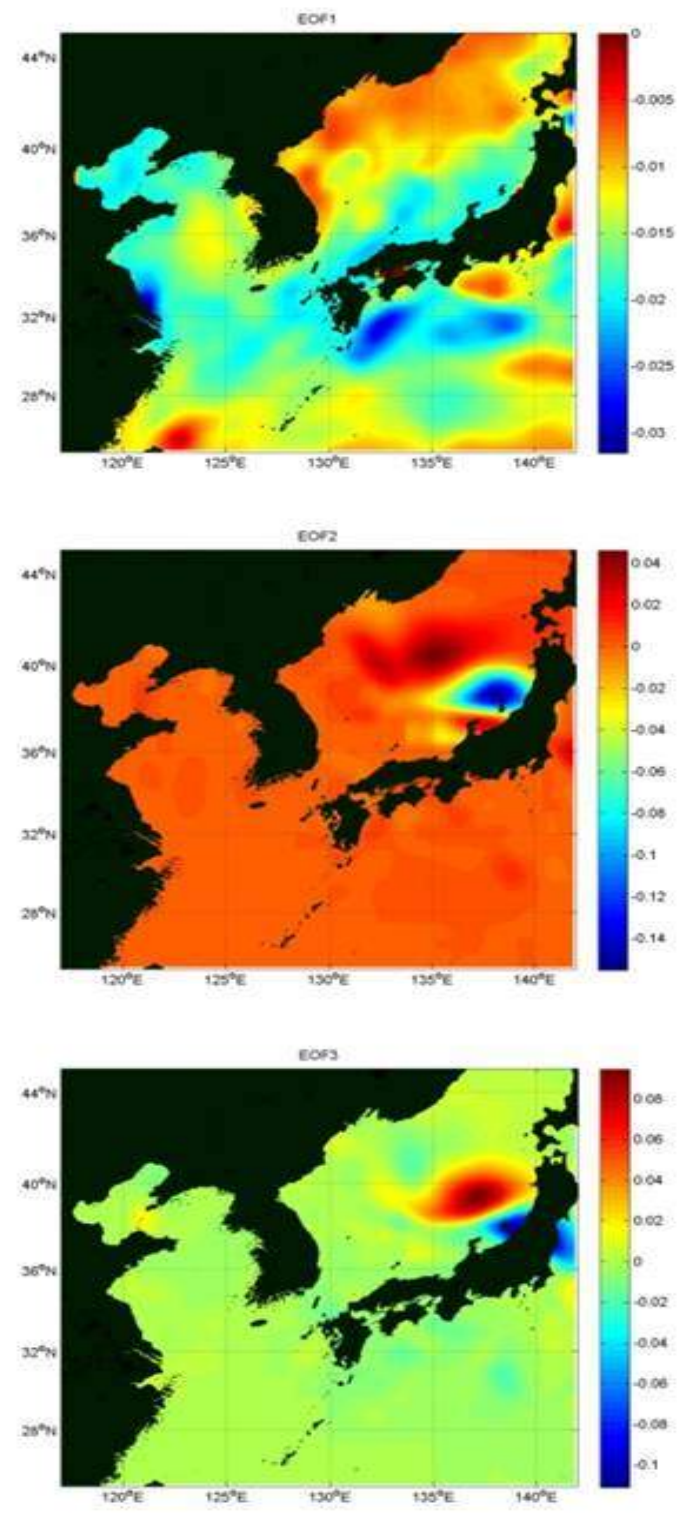

[Fig. 10] EOF of SLA

영향을 많이 받는 해역보다 한반도의 동해 북쪽 으로 해수면의 변화가 큰 것을 알 수 있다. 시간 계수를 살펴보면 해수면 온도의 경우와 마찬가 지로 일정한 변화를 보이는 것을 관찰 할 수 있 다[그림 11]. 이것으로 보아 해수면 역시 해수면 온도와 마찬가지로 계절 변화의 영향을 가장 크 게 받는 것을 알 수 있다. 이러한 계절적인 변화
의 원인으로는 크게 기압과 수온에 의한 효과를 꼽을 수 있다. 우선 기압에 의한 해수면 변화를 보면 본 연구 해역에서의 평균 기압은 여름에 낮고 겨울에 높은 계절적 차이를 보인다. 또한 평균 수온 변화에 의한 해수면 변동도 중요 요 인 중 하나이다. 폭이 넓은 수온의 계절적인 변 화는 고온인 하절기에 해수면을 높여주고 동절 기에 낮추어 주는 역할을 할 것이다. 따라서 본 연구 해역의 mode 1 은 계절적인 변화를 보이고 있고 이것은 주로 해수면 기압과 표층 수온의 변화에 의한 것으로 판단할 수 있으며 그 정량 적인 기여도 파악은 앞으로의 과제이다.

Mode 2의 결과에서는 특이하게 일본의 북쪽 해역에서 큰 변화폭을 보였으며 Mode 3에서도 동일한 해역에서 변화 폭이 큰 것을 관찰 할 수 있었다. 해수면 변화의 $\mathrm{EOF}$ 분석에서 주로 mode 2 는 쿠로시오 해류의 대사행과 유축의 변 화의 영향이며 mode 3은 해류나 동해에서의 해 수순환과 관련된다. mode 2 와 mode 3 에서 나타 난 공간분포 상에서 일본의 북쪽이 변화가 큰 것은 한반도의 동쪽에서 쓰시마 난류와 북한 해 류가 만나 동쪽으로 동진하다가 일본의 대륙을 만나 반시계 방향으로 해류의 이동 방향이 바뀌 며 해수면 변동도 크게 발생하는 것으로 보인다.

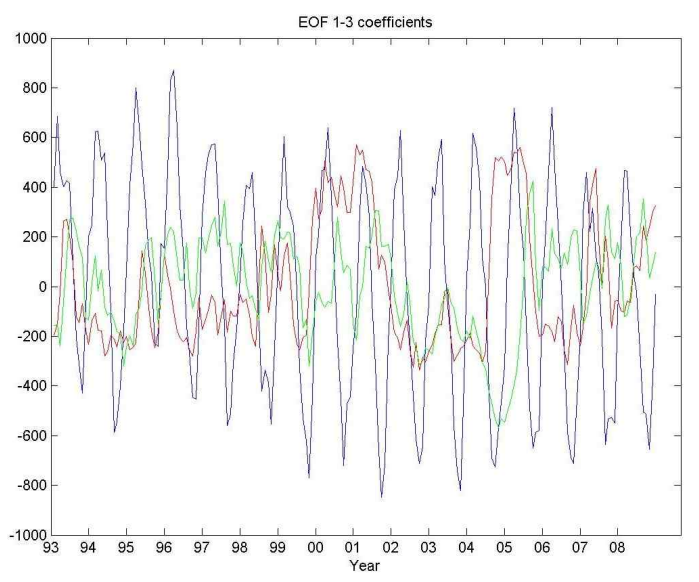

[Fig. 11] Time coefficient of EOF each mode (Blue-mode 1, Red-mode 2, Green-mode 3) 


\section{SST와 SL 비교 분석}

(1) 해역별 위성자료 비교

앞에서 분석해 본 각 해역별 해수면 상승률과 해수면 온도 상승률은 서로 다른 패턴을 가지고 있는 것으로 나타났다. 그래서 두 자료간의 상관 성을 회귀분석 방법을 사용하여 각 해역별로 비 교해 보았다. 그 결과 <표 $3>$ 과 같이 나타났다. 황해에서 0.8442 의 높은 상관성을 보였으며 동해 남부와 동해 북부를 제외한 모든 해역에서 0.7 이 상의 높은 상관 값을 나타냈다.

$<$ Table $3>$ Comparison of time series between SL and SST in each waters

\begin{tabular}{c|c}
\hline Area & $\begin{array}{c}\text { Correlation } \\
\text { coefficient }\end{array}$ \\
\hline \hline Yellow Sea & 0.8442 \\
\hline Northern East China Sea & 0.7752 \\
\hline Southern East China Sea & 0.7212 \\
\hline Shikoku \& Tokai Area & 0.7928 \\
\hline Southern East Sea & 0.5584 \\
\hline northern East Sea & 0.6287 \\
\hline
\end{tabular}

전 연구해역에서 시계열 분석의 결과 일정한 계절변화패턴을 볼 수 있는데 해수면 온도의 Peak가 나타나고 1 2 개월 정도 후에 해수면의 Peak가 나타났다. 이것은 해양에서 해수면 높이 의 변화가 해수면 온도의 변화 후에 발생하는 것을 설명해준다.

(2) 현장 관측자료 비교

<표 4>는 조위관측소에서 관측한 1 시간 간격 의 조위자료와 매일 오전 9시에 관측한 온도자료 와의 상관성을 나타낸 것이다. 조위자료는 온도 자료와 비교하기 위해서 온도 측정 시간인 오전 9시에 관측된 일일 자료를 이용하였으며 두 자료 를 anomaly 데이터로 변환한 후 비교하였다.

위성자료를 이용하여 외해를 비교하였을 때와 마찬가지로 동해해역의 상관성이 다른 해역에 비해서 상대적으로 낮게 나타났으며 시간적으로 도 해수면 온도의 변화 후 해수면의 변화가 일
어나는 것을 확인 할 수 있다.

$<$ Table $4>$ Correlation coefficient of sea level and temperature at costal observation

\begin{tabular}{c|c|c}
\hline \multicolumn{2}{c|}{ Area } & $\begin{array}{c}\text { Correlation } \\
\text { coefficient }\end{array}$ \\
\hline \hline \multirow{3}{*}{$\begin{array}{c}\text { East } \\
\text { Coast }\end{array}$} & Mukho & 0.8604 \\
\cline { 2 - 3 } & Ulleungdo & 0.6864 \\
\cline { 2 - 3 } & Pohang & 0.7497 \\
\cline { 2 - 3 } & Average & 0.7655 \\
\hline \multirow{3}{*}{$\begin{array}{c}\text { South } \\
\text { Coast }\end{array}$} & Geomundo & 0.8882 \\
\cline { 2 - 3 } & Chujado & 0.8958 \\
\cline { 2 - 3 } & Jeju & 0.9097 \\
\cline { 2 - 3 } Yellow & Average & 0.8979 \\
\cline { 2 - 3 } Coast & Mokpo & 0.8200 \\
\cline { 2 - 3 } & Heuksando & 0.9070 \\
\cline { 2 - 3 } & Gunsan & 0.9044 \\
\cline { 2 - 3 } & Average & 0.8771 \\
\hline
\end{tabular}

\section{4. 수온전선 분포 및 분석}

(1) Sobel Edge Detection Method 분석 선행연구에 따라 Sobel Edge Detection Method 를 NOAA/AVHRR 해수면 온도 자료에 적용하 여 임계치 $0.3^{\circ} \mathrm{C}$ 이상의 경사 값을 가지는 해역 을 전선으로 추출하였다(Budgell, 2003). 연구 해 역에서 수온 전선은 크게 네 가지로 나타났는데 추출된 네 가지의 수온 전선은 각기 다른 종류 의 해양 전선의 분류에 해당한다[그림 12].

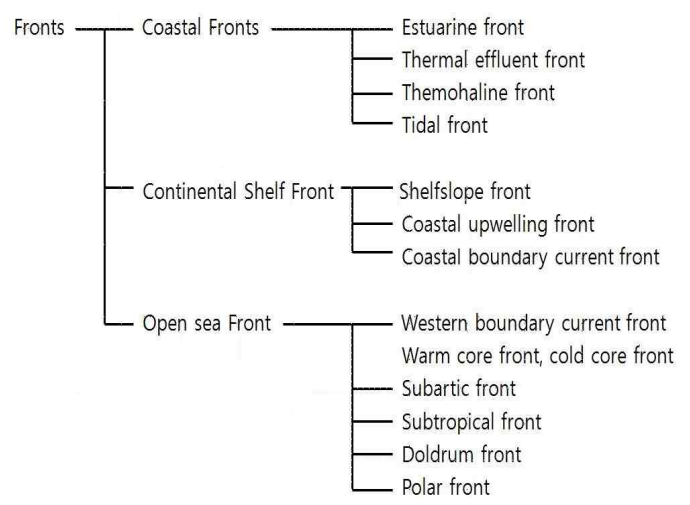

[Fig. 12] Classification of ocean fronts (Yanagi, 1987) 
먼저 동해의 남부와 북부를 구분하는 $39 \mathrm{~N}^{\circ}$ $40^{\circ}, 130 \mathrm{E}^{\circ} \sim 140 \mathrm{E}^{\circ}$ 에 걸친 아극전선, 동중국해상 의 $124 \mathrm{E}^{\circ} 126 \mathrm{E}^{\circ}, 28 \mathrm{~N}^{\circ} \sim 32 \mathrm{~N}^{\circ}$ 에 나타나는 쿠로 시오 전선, 남해 $34 \mathrm{~N}^{\circ}, 125 \mathrm{E}^{\circ} 129 \mathrm{E}^{\circ}$ 에 위치하 는 남해 연안전선, 그리고 황해에서 강한 조석 차에 기인하여 형성되는 조석전선이 나타났다 [그림 13].

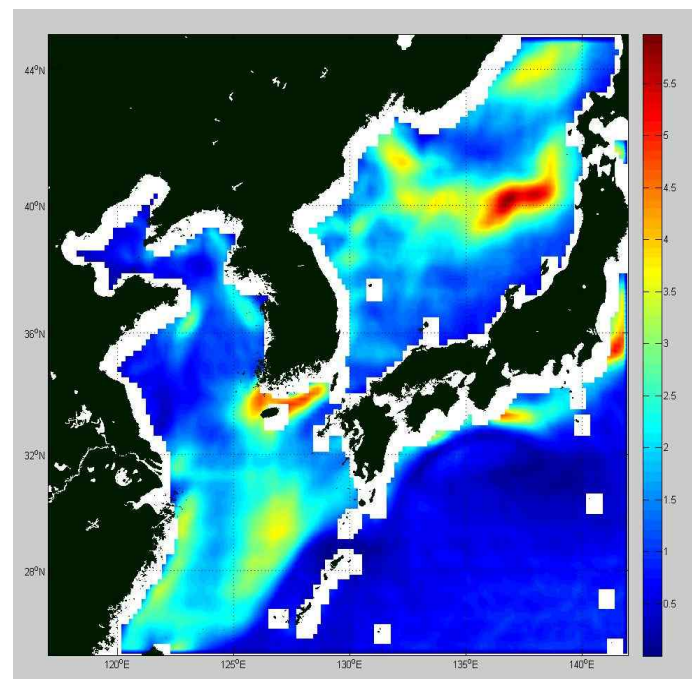

[Fig. 13] Distributions of Thermal Fronts

일반적으로 쿠로시오 전선이라 함은 동경 $150^{\circ}$ 까지 확장되어 일본 남부 해역에 형성되는 것이나 동중국해 해역에 형성되는 쿠로시오 전 선 또한 쿠로시오 해류와 동중국해의 얕은 수괴 에 의해 대륙 경사면 위에 형성되어지는 전선으 로 선행 연구들에 의하면 동중국해에서의 쿠로 시오 전선이라고 할 수 있다(Akio et. al., 1993). 아극전선대는 동해 북부해역으로 유입되는 북한 한류 및 중저층의 동해고유냉수에 따른 한류역 과 남쪽에서 유입되는 쓰시마 난류와 관련된 난 류역에 의해 발생한다. 남해연안전선은 남해 연 안수와 대마난류수괴에 의해 형성되는 것으로 알려져 있다.

Yanagi (1987)가 구분한 해양 전선의 분류를 참고하면 아극전선대는 외양전선의 한 종류이며,
쿠로시오 전선은 대륙붕전선 중 Coastal boundary current front에 해당하며, 남해 연안전선과 서해 조석은 연안전선 중 Thermohaline Front와 Tidal Front에 각각 해당하는 것을 알 수 있다.

(2) 전선 위치 분석

연구 해역에 나타나는 수온 전선은 공간적으 로 살펴 볼 때 조화분해에서 연진폭과 연위상의 경계 영역에서 발생하는 것으로 나타났다. 아극 전선대는 동해 남부와 북부 해역의 경계 해역에 나타났고, 쿠로시오 전선과 남해 연안전선은 동 중국해와 남해의 연진폭과 위상의 경계 해역에 위치하였다.

또한 수온 전선은 해저 지형에 영향을 받아 해저 지형의 경사가 급한 해역에서 발생하였는 데 아극전선은 수심 $3000 \mathrm{~m}$ 대륙붕에서 남으로 수심 1000 2000m로 변하는 경사면에서 발생하 였으며, 쿠로시오 전선은 수심 $100 \mathrm{~m}$ 대륙붕에서 동쪽으로 수심 500 $1000 \mathrm{~m}$ 의 경사면에서 발생하 였다. 남해연안전선은 $20 \mathrm{~m}$ 에서 $100 \mathrm{~m}$ 로 내려가 는 경사면에서 발생하였다 [그림 14].

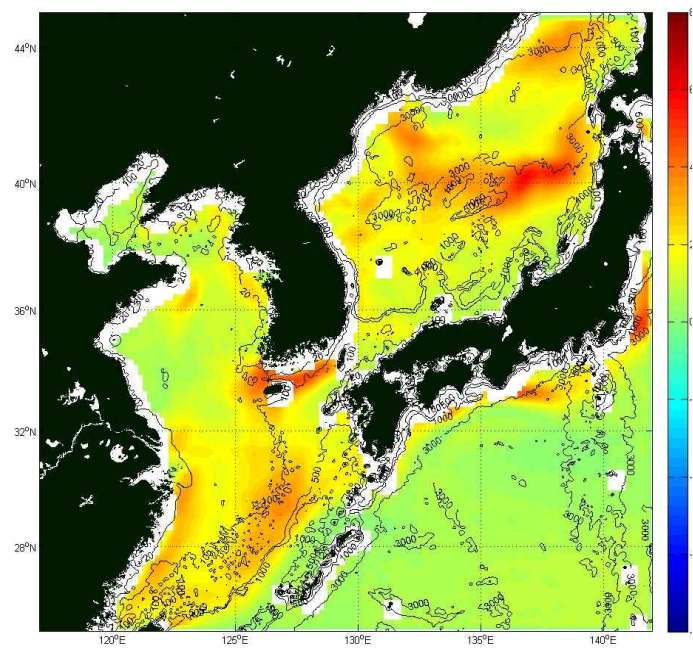

[Fig. 14] Distributions of submarine topography (Black lines and numbers are indicate the depth) and Thermal Fronts in SST gradient image 


\section{$\mathrm{IV}$. 결 론}

본 연구는 북동아시아 해역에서 해수면 온도 와 해수면 변화의 장기변동과 추세를 알기 위하 여 현장 관측 자료와 위성자료를 함께 사용하여 분석하였다.

해수면 온도는 한류의 영향 범위가 축소되고 그 세력이 약해진 결과 동해남부와 동해북부에 서 수온의 상승 폭이 크게 나타났으며 대체적으 로 연 진폭이 높은 곳에서 연위상이 낮게 나타 났으며 연 진폭이 낮은 곳에서 연위상이 높게 나타났다. 그러나 쿠로시오 해류가 지나가는 동 중국해 남부해역의 경우는 연 진폭이 낮은 값을 보였지만 연위상도 낮아 최고 수온을 보이는 시 기가 가장 빨랐다. 이것은 쿠로시오해류가 고온 수를 운반하는 해류이기 때문에 겨울의 대기 영 향이나 북쪽에서 내려오는 한류의 영향을 적게 받기 때문인 것으로 사료된다. 해수면 온도 변화 는 계절 변화의 영향이 가장 큰 것을 알 수 있 으며 공간분포에서는 대륙 쪽에 가까워질수록 수온 변화가 커지는 결과를 보였다.

해수면 변화의 경우 대부분의 해역에서 여름 에 높은 상승률을 나타냈으며 동해남부에서는 겨울에도 쿠로시오 해류의 영향으로 높은 상승 률을 보였으며 한반도의 서해안과 중국의 동쪽 연안에서는 낮은 수심과 큰 조석차 그리고 중국 연안수의 영향으로 인해 모든 계절에 걸쳐 높은 변화 값을 보였다. 연구기간 동안 해수면의 진폭 은 황해에서 다른 해역에 비해 낮은 분포를 보 였고, 동중국해 북부해역과 동해남부에서 평균적 으로 높은 분포를 보였다. 특이점으로는 일본의 남쪽해역에서 쿠로시오 해류의 영향으로 발생하 는 Cyclonic과 Anticyclonic이 나타났다. 또한 울 릉도 주변에서도 동해에서 주기적으로 발생하는 warm eddy에 의해 주변 해역보다 약 $1 ~ 2 \mathrm{~cm}$ 높 은 분포를 보였다.

해수면 고도에 작용하는 영향 중 가장 큰 요
인이 계절변화인 것을 알 수 있었으며 시간 계 수 확인 결과 해수면 온도의 경우와 마찬가지로 일정한 계절 변화를 보이는 것을 관찰 할 수 있 다. 계절적 요인 외에도 해수면에 영향을 미치는 요인으로 쿠로시오 대사행 또는 동해의 해수순 환이 관련 있는데 동해에서 만난 북한 한류와 쓰시마 난류의 움직임에 영향을 받는다.

해수면 상승률과 해수면 온도 상승률의 시계 열 분석 결과 일정한 패턴을 볼 수 있는 데 해 수면 온도의 Peak가 나타나고 1 2 개월 정도 후 에 해수면 고도의 Peak가 나타났다. 또한 해수 면 온도와 해수면의 연 위상을 비교한 결과에서 도 해수면 온도가 최고온도를 기록한 후 1 2개 월 후에 해수면이 최고 높이를 기록하였다. 이것 으로 보아 해수면 온도는 1 2개월 정도의 시간 차(Time lag)를 가지고 해수면을 증가시키는데 기여한다는 것을 알 수 있다.

해양 전선의 경우 연구 해역에서 4 종류의 수 온 전선(아극전선대, 쿠로시오전선, 남해연안전 선, 서해조석전선)을 추출할 수 있었고, 수온 전 선이 발생하는 해역은 수심 변화가 큰 경사면과 해수면온도의 연진폭과 연위상의 변화가 일어나 는 경계와 흡사한 것으로 나타났다.

\section{참고 문헌}

나정열 외(1997). 한국 동해에서의 해면기압, 해 수면 온도와 해상풍의 경험적 직교함수 분석, 한국수산학회지 30(2), 188 202.

박성주(1999). NOAA 원격탐사자료에 의한 한반 도 주변해역의 표면수온 변동, 부경대학교 석 사학위 논문, 61.

서영상 외(2003). 지구환경 변화와 관련된 한국 연근해 해양 이상변동, 한국환경과학회지 12(3), 257 263.

윤용훈 외(2000). 동아시아 지역에서의 Topex/ Poseidon 고도자료와 현상해수면 자료와의 비 교, Journal of the Korean Society of Oceanography 5(4), 267 275.

이석우(1967). 한국연안의 월평균해면의 변화에 
대하여, 한국해양학회지 2, 24 33.

한인성(1998). 쓰시마난류에 의한 동해 열 수송, 부경대학교 석사학위 논문, 35.

Akio, M, Toru, Y. \& Masahito, S.(1993). Fluctuation in Volume Transport Distribution Accompanied by the Kuroshio Front Migration in the Tokara Strait, Journal of Oceanography 49, 231 245.

Budgell W. Paul(2003). Data Fusion Approaches for Merging Marine Remote Sensing Data, LIFECO Deliverables, 7 8.

Berkin I. \& Cornillon P.(2003). SST fronts of the pacific coastal and marginal seas, Pacific Oceanography 1(2), 90 113.

Choi. Y. K., Yang. S. K., Cho. K. D., Lee. J. C., \& Hong. C. H.(1993). Possible formation area of the Japan Sea proper water, Journal of Korean Envi. Sci. Soc 2(1), 27 42.

Everson, R., Cornillon, P., Sirovich, L., \& Webber. A.(1997). Am empirical eigenfunction analysis of sea surface temperatures in the Western North Atlantic, Journal of Physical Oceanography 27(3), 468 479.

Gould W. Richard \& Arnone A. Robert(2004). Temporal and spatial variability of satellite sea surface temperature and ocean colour in the Japan/East Sea, International Journal of Remote Sensing 25(7-8), 1377 1382.

Hickox R., Belkin. I.M., Cornillon. P., \& Shan. Z.(2000). Climatology and seasonal variability of fronts in the East China, Yellow and Bohai Seas from satellite SST data, Geophysical Research Letters 27(18), 2945 2948.
Isoda, Y.(1994). Warm eddy movements in the Eastern Japan Sea, Journal of Oceanography 50, 1 15.

Kang, Y. Q.(1984). Seasonal Variation of Surface Temperatures in the Neighbouring Seas of Korea, Journal of Oceanol. Soc. Korea 19(1), 31 35.

Kang. Y. Q. \& Lee. B. D.(1985). On the annual variation of mean sea level along the coast of Korea, J. Korean Soc. Oceanogr 20, 2 30.

Lie H. J.(1979). Effects of atmospheric pressure and wind stress on daily mean sea level in the bay of Bascay - analysis of continental shelf waves, Journal of Oceanolgical Society of Korea 14(2), 45 53.

Yanagi, T.(1987). Classification of 'siome' streaks and fronts, Journal of Oceanolgical Society of Japan 43, 149 158.

Yoon, H. J.(2001). On Climatic Characteristics in the East Asian Seas by satellite data (NOAA, Topex/Poseidon), Journal of the Korean Environmental Sciences Society 10(6), 423 429.

Youn. Y. H.(2002), Comparison of sea level data from Topex/Poseidon and in-situ tide-gauges in the East sea, Jour, Korean Earth Science Society 23(4), 349 356.

- 논문접수일 : 2012년 03월 08일

- 심사완료일 : 1차 - 2012년 03월 24일 2차 - 2012년 04월 03일

- 게재확정일 : 2012년 04월 07일 